\title{
Model Pembelajaran Two Stay Two Stray dalam Meningkatkan Hasil Belajar Peserta Didik Subtema Perubahan Linkungan di Madrasah Ibtidaiyah
}

\author{
Aswad $^{1}$, Samrin $^{2}$, Samsu $^{3}$ \\ ${ }^{1}$ Institut Agama Islam Negeri Kendari, Indonesia. E-mail: aswadsowa@gmail.com \\ ${ }^{2}$ Institut Agama Islam Negeri Kendari, Indonesia. E-mail: samrinsam75@yahoo.com \\ ${ }^{3}$ Institut Agama Islam Negeri Kendari, Indonesia. E-mail: drs.syamsu.mpd@gmail.com
}

\begin{tabular}{|c|c|}
\hline Articel info & Abstract \\
\hline Artikel history: & This study aims to improve student learning outcomes through the \\
\hline Received; 19 oktober 2020 & implementation of the Two Stay Two Stray learning model on the sub- \\
\hline Revised : 26 Desember 2020 & theme of environmental change. This is a classroom action research \\
\hline Accepted: 3 Juni 2021 & which consists of 2 cycles. The research subjects were 21 students of class \\
\hline & VB MIN 1 Kendari. Data were collected by documentation, learning \\
\hline & $\begin{array}{l}\text { outcomes tests, and observation. The research findings showed that } \\
\text { student learning outcomes on the sub-theme of environmental change can }\end{array}$ \\
\hline & be improved through the implementation of the Two Stay Two Stray \\
\hline & learning model. The students' learning mastery in the pre-cycle was \\
\hline & $23.80 \%$ with an average of 59.14 and increased in the first cycle with \\
\hline & $\begin{array}{l}52.38 \% \text { learning completeness and an average of } 63.80 \text { and again } \\
\text { increased in the second cycle with } 80.95 \text { learning mastery and an average }\end{array}$ \\
\hline & \\
\hline
\end{tabular}

Penelitian ini bertujuan meningkatkan hasil belajar peserta didik melalui penerapan model pembelajaran Two Stay Two Stray pada subtema perubahan lingkungan. Jenis penelitian ini adalah penelitian tindakan kelas yang terdiri atas 2 siklus. Subjek penelitian adalah peserta didik kelas VB MIN 1 Kendari berjumlah 21 siswa. Data dikumpulkan melalui dokumentasi, tes hasil belajar, dan observasi. Temuan penelitian menunjukan bahwa hasil belajar peserta didik pada subtema perubahan lingkungan dapat ditingkatkan melalui penerapan model pembelajaran Two Stay Two Stray. Ketuntasan belajar peserta didik pada pra siklus adalah 23,80\% dengan rata-rata 59,14 dan mengalami peningkatan pada siklus I dengan ketuntasan belajar 52,38\% dan rata-rata 63.80 dan kembali mengalami peningkatan pada siklus II dengan ketuntasan belajar 80,95 dan rata-rata 71.90 .

Keywords:

Keywords satu;

Keywords dua;

Keyword tiga

\section{Two Stay Two Stray (TSTS) \\ Learning Outcomes of Students Thematic Learning}

\section{PENDAHULUAN}

Pendidikan merupakan hal yang sangat penting dalam membangun peradaban bangsa. Lewat pendidikan bermutu, bangsa dan negara akan terjunjung tinggi martabat dimata dunia (Aris Shoimin, 2013.h.20). Sebagai seorang pendidik harus mampu memberikan dorongan yang positif sehingga 
siswa dapat termotivasi dalam mengikuti proses pembelajaran serta menciptakan suasana belajar yang menyenangkan agar siswa bisa berkembang semaksimal mungkin. Hal ini sesuai dengan fungsi dan tujuan pendidikan yang terdapat dalam Undang-Undang RI No. 20 Tahun 2003 pada BAB II pasal 3 yaitu pendidikan nasional berfungsi mengembangkan kemampuan dan membentuk watak serta peradaban bangsa yang bermartabat dalam rangka mencerdaskan kehidupan bangsa, bertujuan untuk mengembangkan potensi peserta didik agar menjadi manusia yang beriman dan bertakwa kepada Tuhan Yang Maha Esa, berakhlak mulia, sehat, berlimu, cakap, kreatif, mandiri dan menjadi warga Negara yang demokratis dan bertanggung jawab (UU RI N0.20 Tahun 2003,h.8).

Berdasarkan sistem pendidikan nasional tersebut, dapat dijelaskan bahwa fungsi dan tujuan pendidikan tidak lain adalah untuk mencerdaskan kehidupan bangsa Indonesia dan untuk menciptakan masyarakat Indonesia yang beradab dan berakhlak mulia. Selain itu, pendidikan juga dapat mendorong peningkatan kualitas manusia dalam meningkatkan kompetensi kognitif, afekif maupun psikomotorik melalui kemampuan yang telah dimilikinya.

Inovasi pembelajaran merupakan suatu hal yang sangat perlu dilakukan oleh seorang guru atau pendidik. Dengan adanya inovasi pembelajaran yang dilakukan oleh guru atau pendidik maka akan menghasilkan suatu proses pembelajaran yang lebih bermakna dan berkesan pada diri peserta didik. Supriadi (2017:2) mengungkapkan Guru harus selalu didorong untuk melakukan berbagai inovasi dan kreativitas dalam pembelajaran agar mutu dari output pembelajaran sangat berkualitas.

Proses pembelajaran dalam dunia pendidikan secara umum melibatkan empat buah komponen utama yaitu siswa, guru, lingkungan belajar dan materi pelajaran. Keempat komponen ini mempengaruhi siswa dalam mencapai tujuan belajar. Setiap siswa mempunyai tingkat kemampuan yang berbeda-beda jika dilihat dari daya tangkap terhadap pelajaran, pengetahuan yang dimilikinya dalam bidang yang dipelajari, keterampilan belajar, tujuan belajar dan lain-lain. Guru harus membimbing siswa dan memberikan motivasi agar dapat mengembangkan pengetahuannya sesuai dengan bidang studi yang dipelajari.

Berdasarkan observasi awal yang dilakukan peneliti terlihat bahwa pelaksanaan pembelajaran Tematik di MIN 1 Kendari masih menggunakan model pembelajaran konvensional. Selain itu, guru dalam menyampaikan materi pembelajaran cenderung monoton sehingga banyak peserta didik yang kurang bersemangat dalam mengikuti proses pembelajaran.

Hasil wawancara dengan salah satu guru kelas V di MIN 1 Kendari terungkap alasan modelmodel pembelajaran yang baru tidak digunakan dalam melaksanakan proses pembelajaran Tematik adalah guru masih kesulitan dalam mencari model yang cocok untuk model pembelajaran tersebut. Selain itu, keterangan dari salah satu peserta didik kelas VB tentang sistem belajar tematik menunjukkan sikap tidak antusias siswa terhadap pembelajaran yang terjadi. Hal ini tentunya berpengaruh negatif terhadap rendahnya hasil belajar yang di peroleh siswa. Hasil ulangan harian yang dilakukan guru terhadap siswa di kelas IV MIN 1 Kendari menunjukkan dari 21 peserta didik yang mengikuti ujian hanya 5 peserta didik yang mencapai nilai standar KKM yang ditetapkan sekolah tersebut (nilai $\geq 70$ ). Data hasil ulangan siswa dapat dilihat pada tabel 1.

Model pembelajaran Two Stay Two Stray (TSTS) adalah Model pembelajaran kooperatif yang memberikan kesempatan kepada kelompok untuk membagikan hasil dan informasi ke kelompok lain. Pembelajaran ini melibatkan seluruh pihak baik guru maupun peserta didiknya. Model Pembelajaran Two Stay Two Stray dapat dijadikan alternatif model pembelajaran yang bisa membantu menciptakan suasana belajar yang efektif dan dapat memberikan kesempatan kepada peserta didik untuk lebih aktif bekerja sama dengan teman selain mendengar penjelasan dari guru saja, sehingga dengan penerapan Model Pembelajaran Two Stay Two Stray diharapkan dapat meningkatkan hasil belajar peserta didik. Suyatno dalam (Fathurrohman, 2015:90) menyatakan model pembelajaran Kooperatif two stay two stray adalah pembelajaran dengan cara peserta didik 
berbagi pengetahuan dan pengalaman dengan kelompok lain dan dua siswa lainnya tetap di kelompokan untuk menerima dua orang dari kelompok lain, kerja kelompok, kembali ke kelompok asal kerja kelompok dan laporan kelompok. Pendapat lain mengungkapkan bahwa model Two Stay Two stray merupakan sistem pembelajaran kelompok dengan tujuan agar peserta didik dapat saling bekerja sama, bertanggung jawab, saling membantu memecahkan masalah, dan saling mendorong satu sama lain untuk berprestasi (Huda, 2013:207).

Penggunaan model pembelajaran Two Stay Two Stray merupakan suatu alternatif guru dalam meningkatkan pemahaman dan kreativitas siswa. Maka diperlukan suatu usaha guru untuk meningkatkan dan menumbuhkan peserta didik seperti antusias, motivasi, keaktifan, dan rasa senang. Dengan demikian, model pembelajaran Two Stay Two Stray merupakan salah satu model yang cocok dipilih guru karena mendorong peserta didik menguasai beberapa keterampilan di antaranya berbicara , menyimak, dan pemahaman pada materi. Sebagaimana penelitian yang dilakukan oleh Yulainingrum pada tahun 2007 dengan judul Penerapan Pembelajaran Kooperatif Model Dua Tinggal Dua Pergi untuk Meningkatkan Hasil Belajar IPA dan Aspek Kognitif Siswa Kelas V MI Wahid Hasyim Malang Tahun Ajaran 2016/2017. Hasil Penelitian menunjukkan terjadinya peningkatan hasil Belajar dan aspek kognitif siswa setelah menggunakan model pembelajaran Dua Tinggal Dua Tamu.

Tabel 1. Hasil Belajar Ulangan Harian Tematik Tema 8

\begin{tabular}{lc}
\hline \multicolumn{1}{c}{ Aspek Pengamatan } & Nilai dan Persentase \\
\hline & \\
Nilai Rata-Rata & 59,14 \\
Jumlah Peserta Didik Tuntas & 5 \\
Jumlah Peserta Didik Tidak Tuntas & 16 \\
Presentase & $23,80 \%$ \\
\hline
\end{tabular}

\section{METODE}

Jenis penelitian ini adalah penelitian tindakan kelas (classroom action research). Penelitian ini dilakukan dalam 2 (dua) siklus, dimana masing-masing siklus terdiri dari perencanaan, pelaksanaan tindakan, observasi serta refleksi. Penelitian ini dilaksanakan di semester genap tahun ajaran 2019/2020 di kelas VB di MIN 1 Kendari selama dua bulan. Populasi dalam penelitian ini adalah peserta didik kelas V di MIN 1 Kendari. Sedangkan sampel penelitian dalam penelitian ini adalah peserta didik kelas VB MIN 1 Kendari yang berjumlah 21 orang. Teknik pengumpulan data dalam penelitian ini dilakukan dengan dokumentasi, tes hasil belajar, dan observasi . Indikator kinerja yang dicapai dalam penelitian ini adalah peserta didik dikatakan tuntas dalam belajar jika telah mencapai standar keberhasilan yang ditetapkan sekolah (nilai $\geq 70$ ). Sedangkan ketuntasan secara klasikal yaitu apabila siswa yang mencapai nilai KKM telah mencapai $80 \%$.

Dalam menentukan nilai rata-rata perolehan hasil belajar menggunakan rumus :

$$
x=\frac{\sum f}{N}
$$

Keterangan :

$\mathrm{X}=$ Jumlah nilai rata-rata yang diperoleh siswa

$\sum f \quad=$ jumlah nilai yang dperoleh setiap siswa

$\mathrm{N} \quad=$ jumlah seluruhsiswa dalam kelas (Sudijono, 2004) 
Untuk menentukan ketuntasan hasil belajar peserta didik menggunakan rumus

$\mathrm{P}=\frac{\Sigma f i}{N} \times 100 \%$

Keterangan :

$\mathrm{P} \quad=$ presentase ketuntasan

$\sum f i=$ jumlah siswa pada kategori ketuntasan belajar

$\mathrm{N} \quad=$ jumlah siswa secara keseluruhan (Supardi, 2006)

Untuk menentukan peningkatan hasil belajar menggunakan rumus

$\mathrm{P}=\frac{\text { postrate }- \text { baserate }}{\text { baserate }} \times 100 \%$

Keterangan:

$\mathrm{P} \quad=$ presentase penigkatan Postrate

Postrate $=$ Nilai sesudah tindakan

Baserate $=$ Nilai sebelum tindakan $($ Aqib, 2001)

Menentukan nilai pada lembar observasi peserta didik dan guru

Nilai perolehan $=$

skor perolehan maksimal $x 100 \%$

(Aqib, 2011)

\section{HASIL DAN PEMBAHASAN}

HASIL PENELITIAN

Sebelum dilakukan tindakan tercatat bahwa dari 21 peserta didik yang mengikuti test, hanya hanya 5 peserta didik yang mencapai nilai KKM dengan persentase ketuntasan belajar sebesar 23,80\%. Sedangankan jumlah peserta didik yang tidak tuntas sebanyak 16 orang dengan persentase ketidaktuntasan sebesar 59,14\%. Ini menunjukan bahwa peserta didik masih belum mengusai materi yang diajarkan dengan maksimal. Namun, setelah tindakan pada siklus I melalui penerapan model pembelajaran Two Stay Two Stray dari 21 peserta didik yang mengikuti tes, terdapat 11 peserta didik yang mencapai KKM, namun jumlah peserta didik yang tidak mencapai KKM sebanyak 10 orang. Ketuntasan secara klasikal pada siklus I mencapai 52,38\% dengan rata-rata 63,80. Peningkatan hasil belajar peserta didik dari pra siklus ke siklus I adalah sebesar 23,80\%.

Setelah dilakukan tindakan siklus II, jumlah peserta didik yang tuntas mengalami peningkatan menjadi 17 siswa dengan persentase ketuntasan belajar mencapai 88,95\%. Namun masih terdapat 4 siswa yang tidak memenuhi nilai KKM. Keempat siswa yang tidak tuntas tersebut 2 diantaranya tidak hadir dan 2 diantaranya nilainya tidak mencapai KKM yang ditentukan oleh sekolah. Peningkatan hasil belajar peserta didik dari pra siklus ke siklus II dapat divisualisasikan pada gambar 1. 


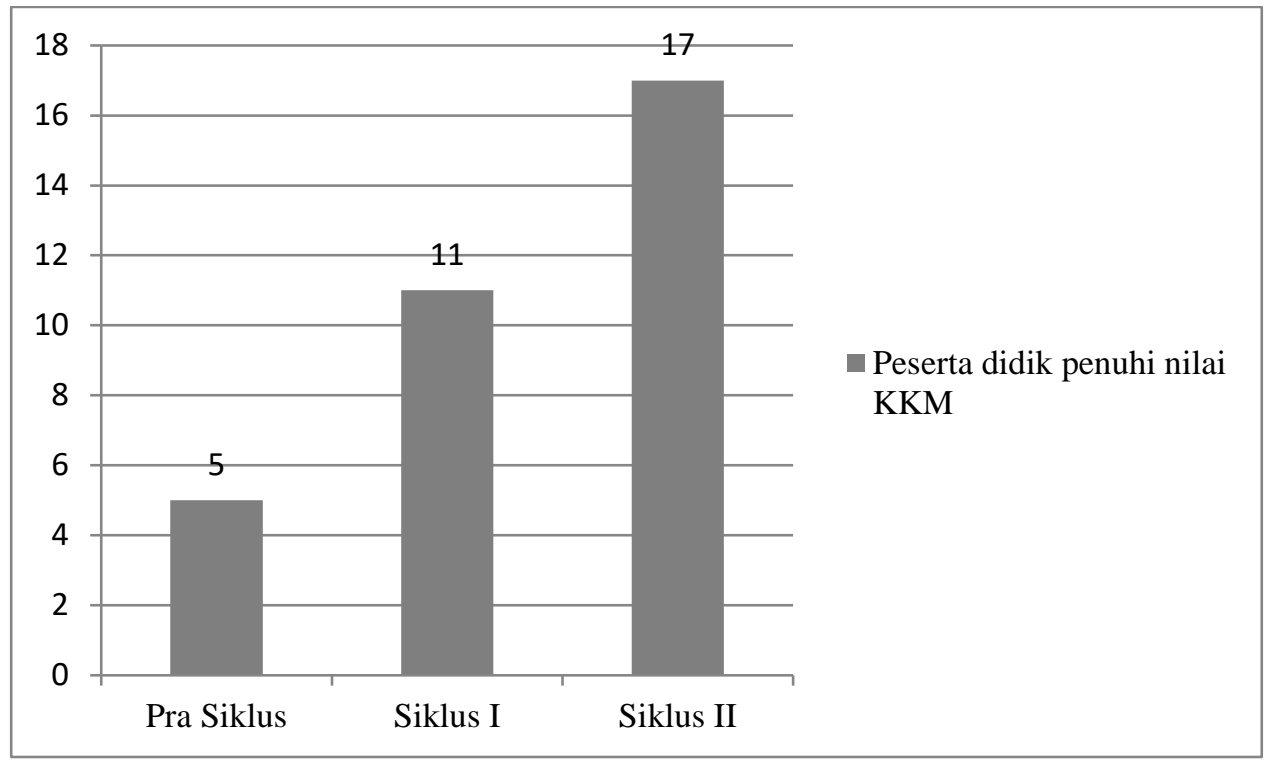

Gambar 1 Bagan peningkatan hasil belajar peserta didik dari tiap siklus

\section{PEMBAHASAN}

Metode pembelajaran Two Stay Two Stray merupakan salah satu metode pembelajaran aktif yang dapat meningkatkan keaktifan dan hasil belajar peserta didik. Karena dengan menggunakan metode pembelajaran Two Stay Two Stray ini peserta didik terlibat langsung dalam proses pembelajaran dan peserta didik juga bekerja dan belajar bersama-sama dengan kelompoknya yang mempunyai kemampuan berbeda-beda. Dengan adanya kerja sama antara peserta didik maka akan membuat peserta didik merasa tidak bosan terhadap pembelajaran dan akan meningkatkan keterampilan sosial peserta didik serta hasil belajar dapat tercapai dengan maksimal.

Pelaksanaan tindakan dimulai dari siklus I yang dilaksanakan sebanyak dua kali pertemuan. Dimana evaluasi diberikan pada saat pertemuan kedua dengan memberikan tes hasil belajar yang berupa soal pilihan ganda untuk mengetahui sejauhmana tingkat pemahaman dan perkembangan hasil belajar peserta didik setelah penerapan model pembelajaran Two Stay Two Stray. Adapun tes hasil belajar pada siklus I dengan persentase ketuntasan sebesar 52,38\% dengan rata-rata $63,80 \%$. Nilai tertinggi 90 dan nilai terendah 20 dengan jumlah peserta didik sebanyak 21 orang. Peserta didik yang tuntas belajar sebanyak 11 orang sedangkan peserta didik yang tidak tuntas sebanyak 10 orang. Hasil tes siklus I ini menunjukan bahwa penerapan model pembelajaran Two Stay Two Stray dapat meningkatkan hasil belajar peserat didik. Sebelum dilakukannya tindakan hasil belajar peserta didik masih banyak yang tidak mencapai KKM, tetapi setelah dilaksanakannya tindakan dengan menerapkan model pembelajaran Two Stay Two Stray maka hasil belajar peserta didik meningkat 12,68\%. Hasil tersebut didukung dengan penelitian Yulianingrum (2017) bahwa penerapan model pembelajaran Two Stay Two Stray (TSTS) dapat meningkatkan hasil belajar siswa pada matapelajaran IPA kelas IX SMP Wahid Hasyim Malang.

Pelaksanaan tindakan siklus II dilakukan selama dua kali pertemuan dimana evaluasi dilakukan di pertemuan kedua dengan memberikan tes hasil belajar yang bertujuan untuk mengetahui sejauh mana tingkatan pemahaman dan peningkatan hasil belajar peserta didik dari siklus I. Adapun perolehan tes hasil belajar siklus II dengan persentase ketuntasan sebesar 80,95\% dengan nilai ratarata sebesar 71,90. Adapun peserta didik yang tuntas belajarnya sebanyak 17 orang dan peserta didik yang tidak tuntas sebanyak 4 orang. Hasil yang diperoleh peserta didik pada siklus II ini sudah mencapai indikator ketuntasan secara klasikal yakni $80 \%$ sedangkan yang diperoleh mencapai $80,95 \%$. Artinya penelitian sudah dikatakan berhasil sehingga penelitian ini tidak dilanjutkan lagi pada siklus 
berikutnya karena hasil belajar Tematik di kelas VB telah meningkat melalui penerapan model pembelajaran Two Stay Two Stray. Hasil tersebut didukung dengan peneltian Rita Jahara (2017) bahwa penerapan model pembelajaran Two Stay Two Stray(TSTS) dapat meningkatkan hasil belajar peserta didik pada mata pelajaran PAI di kelas X MIPA SMA Negeri 1 Tanjung.

Berdasarkan uraian di atas dapat disimpulkan bahwa metode Two Stay Two Stray ini dapat meningkatkan hasil belajar peserta didik, meningkatkan efektivitas pembelajaran dan meningkatkan pencapaian indikator kompetensi. Metode pembelajaran ini dapat dijadikan sebagai alternatif pembelajaran yang mampu meningkatkan keaktifan belajar dan motivasi peserta didik dalam mengikuti pembelajaran. Selain itu, proses pembelajaran akan meningkat apabila metode dan media yang kita gunakan relevan dengan materi yang diajarkan pada saat pembelajaran. Begitupun sebaliknya, jika peserta didik menyukai metode dan media yang kita gunakan maka peserta didik akan termotivasi dalam mengikuti proses pembelajaran sehingga hasil belajar peserta didik meningkat sesuai dengan standar yang telah ditetapkan.

\section{SIMPULAN DAN SARAN}

Berdasarkan hasil penelitian dan pembahasan yang telah diuraikan di atas dapat ditarik kesimpulan bahwa peningkatan hasil belajar siswa dapat dilakukan dengan mengimplementasikan metode pembelajaran Two Stay Two Stray. Dengan diterapkannya metode tersebut, kualitas belajar siswa dari setiap siklus mengalami peningkatan yang begitu baik. Persentase ketuntasan belajar siswa dari pra siklus yaitu di bawah 25\% naik secara signifikan menjadi $80.95 \%$ pada siklus II. Sehingga berdasarkan temuan ini diharapkan penerapan model pembelajaran Two Stay Two Stray dapat dijadikan salah satu alternatif dalam usaha meningkatkan kualitas pembelajaran yang terjadi di kelas.

\section{DAFTAR RUJUKAN}

Aji, Putu Bayu. (2014). Pengaruh Model Pembelajaran Kooperati Tipe Two Stay Two Stray (TSTS) Dengan Pendekatan Saintifik Terhadap Hasil Belajar IPA. Jurnal Pijar MIPA, 2 No 1.

Akib, Z. (2001). Penelitian Tindakan Untuk SMP, SMA. Dan SMK (Bandung). Alam Wijaya.

Akib, Z. (2011). Penelitian Tindakan Untuk Guru SD, SLB. Dan TK. Alam Wijaya.

Andari, D. W. (2013). Penerapan Model Pembelajaran Two Stay Two Stray (TSTS) Untuk Meningkatkan Hasil Belajar PAI Kelas VIII SMP Nurul Islam. Universitas Islam Negeri Malang.

Aziz, A. (2015). Penerapan Model Pembelajaran Two Stay Two Stray untuk Meningkatkan Hasil Belajar IPA Siswa Kelas X SMA Negeri 10 Purworejo Tahun Pelajaran 2013/2014. Radiasi: Jurnal Berkala Pendidikan Mipa, 6(1), 118-121.

Fathurrahman, Muhammad. 2015. Model-Model Pembelajaran Inovatif. Jogjakarta: Ar-Ruzz Media.

Huda, M. 2013. Model-Model Pengajaran dan Pembelajaran. Yogyakarta: Pustaka Pelajar.

Ihsan, M. (2019). Penerapan Metode Pembelajaran Two Stay Two Stray untuk meningkatkan Kemampuan Minat Belajar. Journal of Teaching Dan Learning Research, 1(1), 1-8.

Rulli Marcalena. (2014). Penerapan Model Pembelajaran Two Stay Two Stray dalam Meningkatkan Hasil Belajar Siswa Kelas Vb Pada Mata Pelajaran Ipa di SDN 1 Talaga Besar Kecamatan Talaga Raya Kabupaten Buton Tengah. Skripsi: Jurusan Tarbiyah Prodi PGMI IAIN Kendari

Shoimin, A. (2014). 68 Model Pembelajaran Inovatif Dalam Kurikulum 2013. Arruz Media. 
Sudijono, A. (2004). Pengantar Statistik Pendidikan. PT. Raja Graindo Persada.

Supriadin. D. (2017). Implementasi Manajemen Inovasi dan Kreatifitas Guru dalam Meningkatkan Mutu Pembelajaran. IJEMAR, 1 (2), 125-132.

Sugiyono. (2009). Metode Penelitian Pendidikan Pendekatan Kuantitati, Kualitatof, dan R\&D. Alfabeta.

UU RI, No. 20 Tahun 2003 Tentang System Pendidikan Nasional. (2003). Direktorat Jendral Pendidikan Islam Agama RI.

Widayani P, Putra I, G. N. (2014). Pengaruh Two Stay Two Stray Berbantu Peta Konsep Terhadap Hasil Belajar PKN Kelas V SD Gugus Igusti Ngurah Rai. Jurnal Mimbar PGSD Uniersitas Pendidikan Ganesa, Vol 2. No. 